\title{
Structure, Challenges and Opportunities for Development of Entrepreneurial Education in Russian Universities
}

\author{
Margarita Zobnina ${ }^{\text {a }}$ \\ Associate Professor, mzobnina@hse.ru \\ Anatoly Korotkov ${ }^{b}$ \\ Lecturer, Department of Innovative Pharmaceutics, Medical Technology and Biotechnology, \\ korotkov.av@phystech.edu \\ Aleksandr Rozhkov ${ }^{\text {a }}$ \\ Associate Professor, arozhkov@hse.ru \\ ${ }^{a}$ National Research University Higher School of Economics, 20, Myasnitskaya str., Moscow 101000, Russian Federation \\ ${ }^{\mathrm{b}}$ Moscow Institute of Physics and Technology (MIPT), 9, Institutsky per., Dolgoprudny 141701, Moscow Region, \\ Russian Federation
}

\begin{abstract}
$\mathrm{T}$ his study explores the creation and development of entrepreneurial education tracks in the formation of a University Entrepreneurial Ecosystem (UEE) in certain Russian universities. In particular, the ways in which these tracks promote new venture launches, the commercialization of technologies, and the development of entrepreneurial mindsets and skillsets will be explored.

A panel of 21 Russian Universities was used to verify the integrated UEE model using the method of co-operative inquiry. The role of entrepreneurial courses in UEEs is illustrated herein with the use of 4 cases of Russian universities.

Among the key findings of this research is that the implementation of entrepreneurship education courses configures the UEE development model centered around the education course. UEE formation begins with the personal development of individuals as the course ingrains an entrepreneurial mindset and related skills in students, and attracts entrepreneurs and business angels for mentoring

roles and project development activities. Next, supporting institutions like incubators and accelerators are established from scratch, or existing ones are engaged to assist further student project development. As a result, emerging elements of UEE are actively engaged around the development of student startups.

Further case analysis suggests that the professors' academic background and entrepreneurial experience, as well as the course format (e.g. elective or compulsory) are not a necessary prerequisite for the successful initiation and development of UEE, provided the course is project based and generates a stream of student startups. Professors' skills are complemented through the ecosystem, and some cases describe successful course launches by other ecosystem actors. It is also apparent that many universities pursue entrepreneurship education through sporadic infrastructure development, or through a more detached entrepreneurship course implementation.
\end{abstract}

Keywords: entrepreneurship development; university entrepreneurial ecosystem; entrepreneurial education
Citation: Zobnina M., Korotkov A., Rozhkov A. (2019) Structure, Challenges and Opportunities for Development of Entrepreneurial Education in Russian Universities. Foresight and STI Governance, vol. 13, no 4, pp. 69-81. DOI: 10.17323/2500-2597.2019.4.69.81 


\section{Entrepreneurial Education Development}

Entrepreneurial education has been a growing area at least since modern societies began to transform into entrepreneurial societies [Audretsch, Thurik, 2001]. In 2008, the Global Education Initiative of the World Economic Forum initiated the massive promotion of entrepreneurial education. This was considered to be a key driver for sustainable social development and economic recovery [WEF, 2009]. Further, the EU Commission's Entrepreneurship 2020 action plan includes three action points, the first of which is the development of entrepreneurial education [European Commission, 2013]. It is designed to introduce more entrepreneurship classes to increase the entrepreneurial skills of students [Gorman et al., 1997; Pittaway, Cope, 2007]. As a result, entrepreneurial education is gaining momentum at universities around the world [Katz, 2003, Valerio et al., 2014].

Entrepreneurial education is delivered in various formats, such as separate courses including blended and massive open online courses (MOOCs), certification programs, and full-time bachelor's and master's degree programs. Most programs are heavily embedded in the university infrastructure, enabling students to have access to all kinds of resources and expertise for their business development. The availability of certain practical resources and other support mechanisms can facilitate the adoption of entrepreneurial behaviors, especially by STEM students [Luthje, Kranke, 2003] as well as promote the perception of entrepreneurship as a career option [Johannisson, 1991; Autio et al., 1997]. Entrepreneurial education can motivate students to initiate business projects and spark great ideas. However, such ideas and projects often cannot be developed without further support beyond the course, especially on emerging markets [Alaref et al., 2019]. Hence, the development of entrepreneurial education should be embedded in a contiguous system of institutions, norms, and actors, which are collectively known as university entrepreneurial ecosystems (UEE). Thus, a combination of entrepreneurial actors emerges (both individuals and organizations), institutions, processes, values, and mind-sets interact, which drive the local entrepreneurial environment [Mason, Brown, 2014].

It has been shown in the literature that various forms of entrepreneurial education are an inherent element of a university entrepreneurial ecosystem's origin and development. However, current research lacks evidence regarding whether entrepreneurial education is a significant catalyst for the steady development of a full-fledged entrepreneurial ecosystem. In this paper we explore how introducing entrepreneurial education urges the stakeholders to create coherent entrepreneurial ecosystems at their respective universities. We use Russian universities, which are at the beginning of the ecosystem formation process as the object of this research.

In Russia, entrepreneurial culture and education have been rapidly developing and exhibit great diversity, which enables researchers to observe and analyze emerging ecosystems. In 2010, the Russian government initiated innovation infrastructure development at state universities. A total of 8 billion rubles were allotted among 56 universities over the span of three years from 2010 to 2012. This initiative was expected to boost applied research projects and incentivize universities to participate in startup creation and the training of specialists for innovative industries. As a result, many universities created business incubators and other innovation infrastructure elements. That funding program was designed for three years, with the anticipated results to be revealed over the span of the following five years until 2017. In 2015, the Russian Venture Company (RVC) conducted research [RVC, 2016] into the development of innovative ecosystems at the universities and research centers. It achieved substantial growth (50\%-200\%) for most elements of infrastructure associated with innovation, including labs, business incubators, innovation development departments, and so on. Further research [RVC, 2016] discovered over 50 business incubators and accelerators actively engaged in cooperation with universities.

Despite the substantial development of the innovative infrastructure, RVC reports low awareness of the programs among potential participants and underdeveloped relationships among partners as common issues in the observed ecosystems [RVC, 2017]. This hinders the impact and inhibits the performance of the investments made in establishing some elements of the UEE.

To foster the development of innovation infrastructure, certain institutional actors promoted the entrepreneurial curriculum at universities. The Internet Initiative Development Fund (IIDF) ${ }^{1}$ developed and distributed a blended learning-based (online and offline) 'Internet Entrepreneurship'2 course in 2014. The idea was to combine online lectures and offline project discussion and tracking in order to facilitate

\footnotetext{
The Internet Initiative Development Fund (IIDF) is the largest venture fund for IT startups in Russia, established by the Agency for Strategic Initiatives in 2013. The IIDF invests in early-stage IT startups, offers acceleration programs, and contributes to the development of venture legislation. A total fund of 6 billion rubles was used to secure investments in over 300 companies, with over 10,000 startups involved in various development, education and acceleration programs.

The 'Internet Entrepreneurship' course was developed by Margarita Zobnina at IIDF in 2014. This was a mixed-method (online lectures and offline seminars) and project-based class, aimed at the creation and development of student startups. At the time of writing, it had been implemented into over 150 Russian universities including Lomonosov, MSU, MIPT, ITMO, HSE, and others. Total student intake of the internet entrepreneurship course exceeded 7000 , with a completion rate of over $80 \%$ for the online portion and over 1460 student projects registered on the course platform.
} 
the development of students' projects. Course content was provided to the partner universities for free after faculty members completed an offline "train the trainer" program. After the pilot course implementations, over 163 universities countrywide introduced the course in their curricula. Soon after the course launch, participating universities started to implement various measures to improve output results, including student startup survival rates, funding application success, and so on. Another course, 'Technological Entrepreneurship' was introduced and distributed by the RVC in 2017 to the universities in the same way.

Hence, the implementation of entrepreneurial education pushed the participating universities in Russia to establish and develop a full-fledged entrepreneurial ecosystem within some of the institutions. These initiatives brought new momentum to the startup and entrepreneurial ecosystems present at Russian universities.

To discuss the role of entrepreneurial courses in UEE development at Russian universities in more detail, the paper is structured as follows: first, we consider the available literature on the role of entrepreneurial education in UEEs; second, we explain our research methods; third, we discuss the case studies' findings; and fourthly we present the results and recommendations.

\section{Entrepreneurial Ecosystems at Universities and the Role of Entrepreneurial Courses}

Modern universities are engaged [van de Ven, 1993] in innovations and entrepreneurship, accumulating scientific research through financing and insurance arrangements and through the development of human competence. Some researchers emphasize the importance of the educational component, which differentiates the university entrepreneurial ecosystem from other environments. They emphasize that the UEE framework may be comprised of entrepreneurial courses in different formats targeting various audiences as well as extracurricular studies and discussion options. Such a difference is derived from the fact that UEE display a great structural and compositional variability due to the differences in internal and external factors and their development process [Greene et al., 2010; Isenberg, 2014].

Entrepreneurial education embraces concepts around new venture creation and also has a broad output, including both entrepreneurial mindsets and developing skill sets for entrepreneurs as well as customers, suppliers, and policymakers [Fayolle, Gailly, 2015; Greene et al., 2010; Chepurenko, 2017]. Graduates with entrepreneurial mindsets are more open to new opportunities in many cases. Besides delivering entrepreneurial activities and groups to the gen- eral entrepreneurial community [Feld, 2012], student projects initiated in classes can keep local accelerators and incubators occupied. Given that only a relatively small share of students would continue their projects and become entrepreneurs, it can still help one reach tipping points in the formation of entrepreneurial ecosystems. A critical mass of participants enables 'entrepreneurial recycling' [Mason, Brown, 2014]. This means that entrepreneurs are constantly involved in the ecosystem regardless of their performance. As such, successful founders cash out and invest in the new ventures and failing entrepreneurs also stay in the ecosystem getting another try while the resources are 'recycled' back into high potential ventures [Isenberg, 2011].

As a result, entrepreneurial education becomes an integral part and in some sense the driving motor of the university entrepreneurial ecosystem, along with new venture creation and technology transfer and so on. Does it happen at Russian universities or are there any other specific aspects that need to be considered in the development of the entrepreneurial ecosystem in transitional environments?

\section{Research Methodology and Data Collection}

In order to promote entrepreneurial courses at some universities, we utilized the cooperative inquiry method [Heron, Reason, 2006]. This method suggests the active involvement of the research participant, transferring them from objects of research to active subjects (co-researchers).

The cooperative inquiry method is typically implemented in four stages. Stage 1 requires co-actors to explore the area of interest. In our case, this stage was conducted during the IIDF 'Internet Entrepreneurship' course 'Train the Trainer' in threeday sessions. During the training, academics and university management personnel discussed student entrepreneurship, startups, and drivers of entrepreneurial ecosystem development. As the result of Stage 1, co-researchers developed ideas about implementing entrepreneurial education at their universities. The 'Train the Trainer' sessions for the entrepreneurial course have been conducted six times a year since 2015 with 627 participants in total.

Stage 2 suggests that participants become subjects of the research immersing themselves in the action and also recording their own and peers' results. After the training sessions, participants launched the same entrepreneurship course at their universities and promoted the development of an entrepreneurial ecosystem.

Stage 3 is about full immersion into the problem and active engagement. Some of the settings and preconceptions may be expected to change at this point. At 
this stage, co-researchers will have already acquired extensive teaching experience of Entrepreneurship and will have championed certain changes at their universities as well as established external connections. Certain deviations from the original entrepreneurial ecosystem frameworks were recorded.

Stage 4 allows participants to reassemble and share their ideas and findings on the research problem. In order to exchange findings and observations, co-researchers were invited to the Youth Internet Entrepreneurship Forum ${ }^{3}$ (held on May 22, 2017) and to verify the findings, in-depth interviews with the representatives of 21 universities from 12 regions were conducted. All of the respondents were involved both in teaching and UEE development.

The analysis was conducted as follows. All of the respondents' answers were distributed among the previously described elements of the entrepreneurial ecosystem (see Figure 1). Next, we outlined key concepts and qualitative characteristics of ecosystem development mentioned by the respondents. Each of these suggested elements were then supplemented by a set of qualitative descriptors and quantitative indicators. In order to cross-validate the suggestions received, we completed a set of additional interviews to achieve consistency of the indicators in the model (Tables 1 and 2).

The cases of Russian universities we collected should help to test our following research questions:

1) What is the role of entrepreneurial education in the development of the university entrepreneurial ecosystem?

2) What are the drivers of entrepreneurial ecosystem development at Russian universities?

3) What is the role of the professor who introduces entrepreneurial courses?

4) What are the main challenges and barriers for UEE development at Russian universities?

\section{Russian Universities' Ecosystems in Emergence: Research Findings of the Case Studies}

The primary goal of the University Entrepreneurial Ecosystem (UEE) is to enable and facilitate student startup development. This vision is shared by all of the university representatives participating in the study. Based on an analysis of the interviews and university observations, we validated the University Entrepreneurial Ecosystem Model, which embodies and illustrates the key elements for UEE composition and functioning (Figure 2).
Using the case analysis, we explored the activation and development of the UEE, paying attention to entrepreneurial education as the catalyst for this process. First, we describe several development patterns for different types of universities (Table 3 ) and programs, as well as development drivers.

\section{Case A. Individual Efforts}

This is a typical example of how a course professor (Professor A) became the driver for entrepreneurship mainstreaming, entrepreneurial event organization, and a student startup support system.

The 'Entrepreneurship' course was first taught in the fourth year of a bachelor's degree program in physics in 2015 after Professor A completed a 'Trainthe-Trainer' program. During the first year of implementation, the course was available as an elective module for the Faculty of Physics and Technology, with 22 students in total. In the second year (2016), the course became compulsory in the Faculty of Business Informatics and in 2017, for the Faculty of Management. The rapid advancement of the 'Internet Entrepreneurship' course was made possible due to several reasons besides the motivation and initiative of Professor A. When analyzing the course's performance, it became apparent that "Students from a single program deliver one-dimensional projects with a very weak business component. The course should become interdepartmental in the future." Another reason for the course's promotion was that it was in line with University A's strategic goals: "Our region" has a brain drain problem: talented students get their high USE (Unified State Exam) grades and leave for good. If we can engage them in startups they will stay."

Certain support events and initiatives were also launched. After the first year of course delivery, a student startup competition was organized with a partner university with over 70 participants. The best projects were invited to a startup summer school where they worked with their projects receiving expert tracking. Finally, startups entered pitch competitions, with grants awarded to the top three projects.

As the course progressed it became apparent that students were engaging in startup creation and development during the course, but abandoned these projects after the course was complete: "Students were interested, but it was the graduating class, with great diploma and internship commitments, so they just quit the projects."

In order to provide a nurturing environment for startup development, Professor A started a business incubator with a rolling program for residents and office space at the university. It was aimed at student proj-

\footnotetext{
${ }^{3}$ https://forum2017.iidf.ru/ (in Russian)

${ }^{4}$ This region belongs to underdeveloped regions of Russia as regards the RGDP per capita at 205 thousand rubles (ca. 3500 USD), ranking 50th-60th among Russian regions.
} 


\section{Figure 1. Model of a University Entrepreneurial Ecosystem}

Entrepreneurship ecosystem key principles (philosophy)
University institutional environment

Startup community engagement

Online and offline spaces

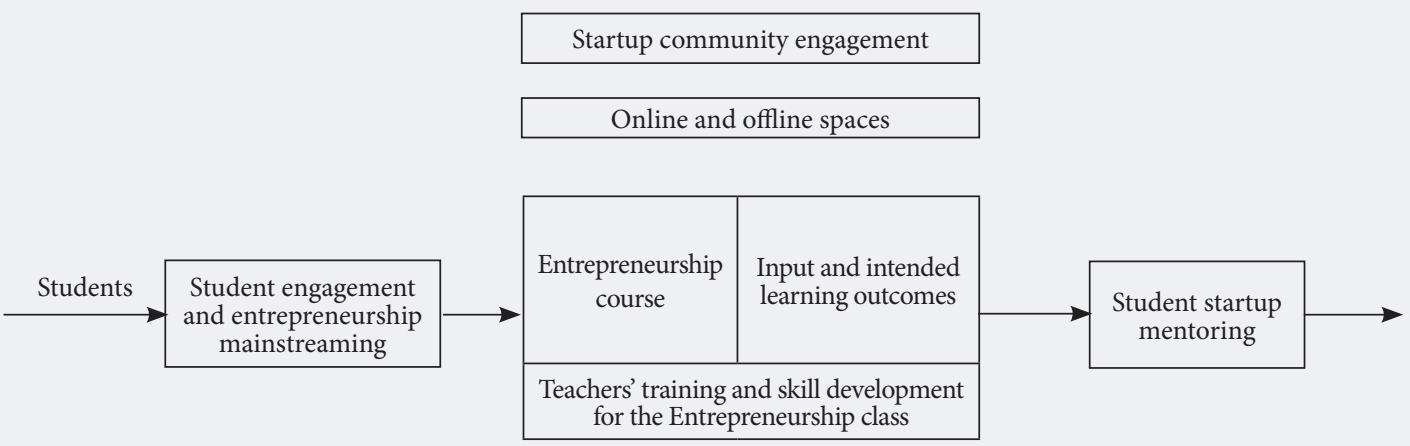

Entrepreneurship ecosystem

ethical principles

University ecosystem monitoring

Source: adopted from [Korotkov, Zobnina, 2019], and CDIO standards.

\section{Table 1. Ecosystem Elements Development by University}

\begin{tabular}{|c|c|c|c|c|c|c|c|c|c|c|c|c|c|c|c|c|c|c|c|c|c|}
\hline Indicator & U1 & $\mathrm{U} 2$ & U3 & $\mathrm{U} 4$ & U5 & U6 & U7 & U8 & U9 & U10 & U11 & U12 & U13 & U14 & U15 & U16 & U17 & $\mathrm{U} 18$ & U19 & $\mathrm{U} 20$ & U21 \\
\hline Number of stud & 14 & 35 & 25 & 35 & 20 & 15 & 17 & 4.3 & 22.8 & 18.4 & 0.33 & 21 & 9.7 & 29 & 2 & 8.9 & 2.7 & 11.1 & 30.6 & 33 & 7.5 \\
\hline University type $^{1}$ & $\mathrm{~T}$ & $\mathrm{C}$ & $\mathrm{E}$ & $\mathrm{E}$ & $\mathrm{C}$ & $\mathrm{T}$ & $\mathrm{T}$ & $\mathrm{E}$ & $\mathrm{T}$ & $\mathrm{C}$ & $\mathrm{E}$ & $\mathrm{T}$ & $\mathrm{C}$ & $\mathrm{T}$ & A & $\mathrm{C}$ & $\mathrm{E}$ & $\mathrm{T}$ & $\mathrm{E}$ & $\mathrm{T}$ & $\mathrm{T}$ \\
\hline $\begin{array}{l}\text { Internet Entreprene } \\
\text { course (years) }\end{array}$ & $\underset{\sim}{\stackrel{0}{\sim}}$ & 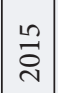 & 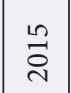 & $\stackrel{n}{\stackrel{n}{2}}$ & $\frac{n}{\stackrel{2}{n}}$ & 足 & $\stackrel{n}{\stackrel{n}{\sim}}$ & 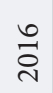 & $\underset{\sim}{\stackrel{0}{*}}$ & $\stackrel{n}{\stackrel{n}{\sim}}$ & $\stackrel{\circ}{\stackrel{0}{\sim}}$ & $\underset{\sim}{\stackrel{n}{2}}$ & $\stackrel{n}{\stackrel{n}{2}}$ & $\underset{\sim}{\stackrel{0}{\sim}}$ & $\stackrel{\circ}{\stackrel{0}{i}}$ & $\underset{\sim}{\stackrel{n}{2}}$ & $\stackrel{\sim}{\stackrel{n}{*}}$ & $\stackrel{n}{\stackrel{n}{N}}$ & $\stackrel{n}{\stackrel{n}{2}}$ & $\stackrel{0}{\stackrel{2}{\sim}}$ & 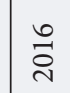 \\
\hline Region Population (mln) & 12.6 & 4.3 & 12.6 & 12.6 & 1.3 & 3.9 & 12.6 & 1.4 & 1.3 & 0.97 & 1.3 & 12.6 & 0.98 & 12.6 & 12.6 & 0.3 & 3.2 & 5.4 & 12.6 & 5.4 & 12.6 \\
\hline $\begin{array}{l}\text { Region GDP per capita, in } \\
\text { thousand USD }^{2}\end{array}$ & 19.3 & 7.6 & 19.3 & 19.3 & 3.6 & 8.3 & 19.3 & 4.3 & 7.3 & 14.5 & 6.1 & 19.3 & 3.1 & 19.3 & 19.3 & 3.7 & 5.9 & 11.1 & 19.3 & 11.1 & 19.3 \\
\hline $\begin{array}{l}\text { University institutional } \\
\text { environment }\end{array}$ & 0 & ++ & + & ++ & ++ & ++ & ++ & ++ & ++ & ++ & ++ & ++ & ++ & + & + & ++ & ++ & ++ & ++ & ++ & ++ \\
\hline $\begin{array}{l}\text { Student engagement } \\
\text { and entrepreneurship } \\
\text { mainstreaming }\end{array}$ & + & ++ & ++ & + & ++ & + & + & ++ & + & ++ & ++ & ++ & ++ & ++ & ++ & + & ++ & ++ & ++ & ++ & + \\
\hline Entrepreneurship course & 0 & ++ & 0 & + & + & 0 & + & ++ & 0 & ++ & + & + & ++ & ++ & - & ++ & ++ & ++ & + & ++ & + \\
\hline $\begin{array}{l}\text { Teachers' training and } \\
\text { skill development for the } \\
\text { Entrepreneurship class }\end{array}$ & + & ++ & + & + & + & + & + & + & + & ++ & ++ & + & + & + & + & + & + & + & ++ & + & + \\
\hline Student startup mentoring & 0 & ++ & + & + & ++ & ++ & 0 & 0 & ++ & ++ & ++ & + & ++ & ++ & - & + & ++ & ++ & ++ & ++ & 0 \\
\hline $\begin{array}{l}\text { Startup community } \\
\text { engagement }\end{array}$ & 0 & ++ & 0 & + & ++ & 0 & ++ & + & + & ++ & + & + & ++ & 0 & + & + & ++ & ++ & ++ & ++ & ++ \\
\hline Online and offline spaces & + & ++ & 0 & + & + & 0 & + & + & + & ++ & - & ++ & ++ & ++ & - & 0 & ++ & ++ & + & + & ++ \\
\hline $\begin{array}{l}\text { University ecosystem } \\
\text { monitoring }\end{array}$ & + & ++ & 0 & ++ & + & + & - & - & 0 & ++ & 0 & 0 & + & ++ & - & - & + & ++ & + & + & + \\
\hline \multicolumn{22}{|c|}{$\begin{array}{l}\text { Notes: }{ }^{1} \mathrm{~T} \text { - technical university, C - classical university ("state universities"), E - Economics and management universities, A - art and/or design } \\
\text { university; }{ }^{2} \text { - data from Rosstat. For the meanings of the codes “++" “+", "0" and “--" see at Table } 2 .\end{array}$} \\
\hline
\end{tabular}




\section{Table 2. Meaning of codes for some indicators provided at Table 1}

\begin{tabular}{|c|c|c|c|c|}
\hline Indicator & ++ & + & $\mathbf{0}$ & - \\
\hline $\begin{array}{l}\text { University institutional } \\
\text { environment }\end{array}$ & $\begin{array}{l}\text { Entrepreneurship is supported on } \\
\text { university level }\end{array}$ & $\begin{array}{l}\text { Entrepreneurship is } \\
\text { supported on faculty level }\end{array}$ & $\begin{array}{l}\text { Considered important } \\
\text { with no formal support }\end{array}$ & $\begin{array}{l}\text { Not } \\
\text { important }\end{array}$ \\
\hline $\begin{array}{l}\text { Student engagement } \\
\text { and entrepreneurship } \\
\text { mainstreaming }\end{array}$ & $\begin{array}{l}\text { Organise events to engage students } \\
\text { in entrepreneurship, share students' } \\
\text { startup success stories at university } \\
\text { webpage/blog, inform students } \\
\text { about entrepreneurial events outside } \\
\text { university }\end{array}$ & $\begin{array}{l}\text { Organise events to engage } \\
\text { students in entrepreneurship }\end{array}$ & $\begin{array}{l}\text { Consider important but } \\
\text { is not formally organised }\end{array}$ & $\begin{array}{l}\text { Not } \\
\text { important }\end{array}$ \\
\hline Entrepreneurship course & University-wide course/minor & $\begin{array}{l}\text { Course on one/several } \\
\text { programs }\end{array}$ & $\begin{array}{l}\text { Don't have } \\
\text { entrepreneurial course }\end{array}$ & - \\
\hline $\begin{array}{l}\text { Teachers' training and } \\
\text { skill development for the } \\
\text { Entrepreneurship class }\end{array}$ & $\begin{array}{l}\text { Course teacher had special training } \\
\text { to deliver entrepreneurial course } \\
\text { and works in startup incubator/ } \\
\text { accelerator/venture fund }\end{array}$ & $\begin{array}{l}\text { Course teacher had } \\
\text { special training to deliver } \\
\text { entrepreneurial course }\end{array}$ & $\begin{array}{l}\text { Consider it important, } \\
\text { but don't have a specially } \\
\text { trained teacher/tutor }\end{array}$ & $\begin{array}{l}\text { Not } \\
\text { important }\end{array}$ \\
\hline $\begin{array}{l}\text { Student startup } \\
\text { mentoring }\end{array}$ & $\begin{array}{l}\text { Students startups are mentored \& } \\
\text { supported by special university unit } \\
\text { and are introduced to the external } \\
\text { accelerators/funds }\end{array}$ & $\begin{array}{l}\text { Special university unit } \\
\text { that mentors and supports } \\
\text { student startups (incubator/ } \\
\text { accelerator) }\end{array}$ & $\begin{array}{l}\text { Consider it important, } \\
\text { but mentoring and } \\
\text { support is provided only } \\
\text { by the course teacher }\end{array}$ & $\begin{array}{l}\text { Not } \\
\text { important }\end{array}$ \\
\hline $\begin{array}{l}\text { Startup community } \\
\text { engagement }\end{array}$ & $\begin{array}{l}\text { University regularly organises } \\
\text { events with/for the startup } \\
\text { community, course teacher is } \\
\text { actively participating in the startup } \\
\text { community }\end{array}$ & $\begin{array}{l}\text { Entrepreneurs, investors, } \\
\text { accelerators' representatives } \\
\text { participate in the } \\
\text { entrepreneurial course }\end{array}$ & $\begin{array}{l}\text { Is important but is not } \\
\text { formally organised/ } \\
\text { systematic }\end{array}$ & $\begin{array}{l}\text { Not } \\
\text { important }\end{array}$ \\
\hline Online and offline spaces & $\begin{array}{l}\text { University has both online } \\
\text { communities/blogs on } \\
\text { entrepreneurship and offline } \\
\text { spaces for entrepreneurs (fab labs, } \\
\text { coworking etc.) }\end{array}$ & $\begin{array}{l}\text { Have either online or offline } \\
\text { space }\end{array}$ & $\begin{array}{l}\text { Is important but are not } \\
\text { formally organized }\end{array}$ & $\begin{array}{l}\text { Not } \\
\text { important }\end{array}$ \\
\hline $\begin{array}{l}\text { University ecosystem } \\
\text { monitoring }\end{array}$ & $\begin{array}{l}\text { Monitor number of students of } \\
\text { entrepreneurial courses, course } \\
\text { feedback and track startups after the } \\
\text { course }\end{array}$ & $\begin{array}{l}\text { Monitor number of students } \\
\text { of entrepreneurial courses } \\
\text { and course feedback }\end{array}$ & $\begin{array}{l}\text { Is important but is not } \\
\text { formally organised/ } \\
\text { systematic }\end{array}$ & $\begin{array}{l}\text { Not } \\
\text { important }\end{array}$ \\
\hline \multicolumn{5}{|l|}{ Source: authors. } \\
\hline
\end{tabular}

ect support and mentoring after the course, and a soft handover to the regional business incubator, external accelerators, and related funds. In November 2017, the business incubator was created and Professor A took the lead.

During the initial course run in the spring of 2016, the first promotional and engagement events like 'hackathons' and 'harvests' were introduced to the mainstream entrepreneurial culture among students. Another advancement was made in 2017, as University A became the regional operator for the 'You are an Entrepreneur' federal program. ${ }^{5}$ This gave a significant boost to entrepreneurial development with quite diverse results: "Many companies were registered, though not so many in the Internet business. Mostly cafes, bakeries, transport, and logistics. Someone is making soap, someone opened an art studio."

After becoming the business incubator leader, Professor A started to promote entrepreneurship be- yond student audiences, targeting the general population broadly and secondary school students in particular: "We want to work with [school students] and engage them so that they become resident startups and stay at the university." School engagement events were launched in December 2017, including a business competition with a 50,000-ruble prize and 28 participant teams (over 130 students). Also in 2017, a total of 11 of the region's 21 districts were visited with demonstrative lessons and entrepreneurship talks.

Regional entrepreneurs were invited to participate in the course, including recognized restaurant owners and owners of media agencies.

Another challenge that shaped the further development of the entrepreneurial ecosystem was the rather small and low-density population of the region, with a substantial rural area (41\%). This justified entrepreneurial and expert community coordination, as

${ }^{5}$ This is a federal program for entrepreneurship education and development by the Federal Agency for Youth. 
Table 3. Case Universities profiles

\begin{tabular}{|c|l|l|l|}
\hline Case & \multicolumn{1}{|c|}{ Type of University } & Number of Students & \multicolumn{1}{|c|}{ Ratings } \\
\hline A & Classical regional university (2.0) & $10000+$ & No \\
\hline B & $\begin{array}{l}\text { Economics-centered, high profile research university, situated in a large } \\
\text { city (1 mln +) }\end{array}$ & $\approx 3000$ & No \\
\hline C & Classic research university 2.0, regional & 18000 & $\begin{array}{l}211-220 \text { B QS World } \\
\text { University Rankings: BRICS }\end{array}$ \\
\hline D & Economics university 1.0 & 2500 & No \\
\hline Source: authors.
\end{tabular}

Professor A stated: "I see a goal to set up communication, to create a common environment. If we duplicate each other there will be not enough people to work with." University A's business incubator established partnerships with the Center for Business Education of the regional Chamber of Commerce and Industry and the Center for Youth Entrepreneurship Development. These centers held entrepreneurial workshops and training events as well as provided speakers and organizational support. As a result of these coordination efforts, every stakeholder had a complementary educational and development track. University courses and business incubators were at the pipeline entry and helped new entrepreneurs formalize their ideas. At the next stage, startups were sponsored by different stakeholders, including the Center for Business Education, the Center for Engineering, and the Regional Development Fund. Upon further development, startups could proceed without external funding or enter federal accelerators and access investments from federal funds.

\section{Case B. External Project Commercialization}

University B has had a Center for Entrepreneurship since 2011 with a youth club for student project development and entrepreneurial events. In October 2018, a business club for school students was established. The Center for Entrepreneurship attracted students from all the city's universities to attend entrepreneurs' talks, promoted entrepreneurship, and familiarized participants with the basic concepts of entrepreneurship. The youth club was an entry point for the master's program in venture business.

A course in entrepreneurship was launched in 2015 in the master's program. By design, the internet entrepreneurial course was project-based and students were expected to create startups as they progressed through the course. Professor B decided to engage external business companies to provide the students with 'real' projects.

Initially, the projects were selected by Professor B from the local business incubator or business angel association. Eventually, an agreement with the local research institute of the Russian Academy of Sciences was established in order to source prospective technological projects. Students were focused on the projects' development and commercialization, including market analysis and business model development as well as on turning it into business. As Professor B explained: "We pitch projects to the students enrolled into our specialization and they arrange themselves into teams of three to five people. After that we check if any skills and competencies are missing and invite relevant people to join the project. If we need a programmer skillset, we invite a student from the faculty of business-informatics. In general, the teams are made up of our students".

Every project had a company supervisor and external mentor. Early stage projects got an academic instructor and later stages involved actual entrepreneurs. If a project developed into a real business, the students continued working there after graduation. If a project team decided to leave after the course ended, the project could be offered for further development to the subsequent student teams.

Another step to enrich the entrepreneurial environment was the creation of University B's accelerator in 2018. With a team of 10, it functioned as a technology transfer center and provided consulting on sales and marketing. It also aided students with attracting financing through grants from The Foundation for Assistance to Small Innovative Enterprises (FASIE) and investments from venture funds and business angel associations. "Due to these activities we became a center of attraction for entrepreneurs", said Professor B.

\section{Case C. Business Incubators Lead Generation and Promotion}

This course was introduced in January 2016 as an optional class for bachelor's students from different departments with two study groups and 50 students in total.

The course in which Professor $C$ was a staff member from the university's business incubator was introduced to generate an inbound flow of student projects: "It would be very beneficial for us to acquire 
student projects started during the course as our residents. After the course ends, we support the projects through our business incubator programs."

Thanks to Professor C, the university's business incubator had a direct interface with the course and actively engaged in both project mentoring and course participant recruitment. The business incubator held various events twice a month including hackathons, business games, meetings with entrepreneurs, film screenings, and case championships. During these events, participants were recruited to enroll in the optional class.

Such a diversity of events allowed for the targeting of different groups at the same time: if a participant already had a startup he could apply to the incubator directly, if he had an idea or the motivation to study, course enrollment was offered.

Local and regional entrepreneurs joined class sessions, eager to share their experience and give feedback. In addition, staff members, incubator residents, and students from University C's business school also participated in the courses. As Professor C described it: "We had cases when a person would come to give a master-class and a student would start doing business with him."

The optional class format translated into flexible attendance and the absence of a compulsory exam or grading. Professor $\mathrm{C}$ had mixed feelings about this: "Optional class is difficult as sometimes they come and sometimes they do not. But they are much more motivated. During the course we discussed real examples and success stories so that students would believe that it is possible to succeed. Besides that, we watched and discussed movies on Saturdays and everyone enjoyed it. By the end of the course nearly half of the 50 students left but that group produced four valid projects." Students, however, did not apply to the regional venture fund: "Many of the students were not ready to take personal responsibility." They participated in different grant programs and competitions instead: Umnik (FASIE), Generation S (RVC), Startup Tour (Skolkovo), Preactum, and a regional techno park. As Professor C summarized: "We plan to create an acceleration program for our students next fall and include an internet entrepreneurial course in the curricula. But it will still be available to everybody."

\section{Case D. The Development of External Connections}

The course was implemented in 2016 as a compulsory course for the third year bachelor's students of the management department (three groups, $80+$ students).

Professor D was an academic without entrepreneurship experience, but she completed the 'Train the Trainer' program for the course. After the first year of teaching the course, Professor D decided to start her own business to get a deeper understanding: "It is quite difficult to give students valid feedback af- ter you have only completed a three-day instructors' course. I tried to launch my own internet project to immerse myself in this activity and applied for an IIDF accelerator."

Professor D also invited experienced entrepreneurs for mentoring during the course: "We need some mentoring if we want to get any results" and to motivate the students: "at some point they are disappointed and frustrated, their hypothesis collapsed and they do not know what to do. And someone has to shake them up."

University D did not have its own business incubator, but there were a regional business incubator and a corporation for SME development. They were ready to support students' projects at the later stages: "A business incubator told us - 'transfer projects to us and we will take care of them." After that, Professor D started to search for mentors and influencers in the entrepreneurial community around the course at her own initiative: "Currently I do it alone. I communicate with the entrepreneurial community by myself, and I managed to sign up 15 experts. We had a startup event in our region; I recruited mentors from its pitch session and some experts agreed. Now they join the classes. The expert board including IT entrepreneurs, government officials, and the business incubator's staff members judge the final pitches for the course."

It turned out that management students lacked important skills for project creation and Professor D tried to establish networks with the regional classic university (19,000 students, 35 educational tracks) that had IT students: "Recently I have been trying to communicate with University X that has IT students. No inter-university teams have been formed yet."

\section{Discussion of Results and Recommendations}

As we observed through the discussed cases, entrepreneurial course implementation is a great catalyst for the development of a UEE, but it can be easily inhibited by various internal and external factors that hinder or halt progress.

We combined the content according to the suggested ecosystem model elements. Relevant citations from the interview transcripts were provided. Please refer to the Table 1 for the course profiles.

\section{The rigidity of the university institutional environment as a barrier to entrepreneurial education and UEE formation}

Certain incoherence is evident between management levels at universities in terms of university entrepreneurship mainstreaming. In some cases, the university rector approved entrepreneurial course implementation but middle management was reluctant and gave no support. As a result, we identified 
a heavy dependence upon proactive and ambitious individuals in cases where support from the middle management is lacking (U1, U2, U9, U17). To give an example: "I initiated the entrepreneurial course and the rector approved it. But they will not let me include it in the curriculum yet. The chairs of the departments and the deans approved the experiment. But it is not official yet. No order has been issued." (U9) Or: "I got this 'train the trainer' program invitation directly from the rector. We discussed it. But after that it has to be dealt with by middle management and they are not interested. The department head had some more important things to think about. He said 'Let us wait and see how it goes." (U1)

The inertia and rigidity in new format and new course adoption, reams of paperwork, and as a result, a lack of systematic work are the results (U1, U3, U9, U12, U16). As one interviewee mentioned: "They cannot adopt entrepreneurial courses into the study plan because of the curriculum design. Bachelor programs do not have such opportunities, nor do master's. We cannot adopt the course as the Federal State Education Standards for engineers do not include ${ }^{6}$ entrepreneurial competencies" (U12).

\section{Student engagement and entrepreneurship mainstreaming}

The process of student engagement and entrepreneurship mainstreaming also required additional attention and development. As a result of this lack of prioritization, students did not understand why studying entrepreneurship was necessary for them (U1, U2, U5, U6, U7, U8, U9, U13, U14, U15, U16). As one informant said: "It turned out that exchange students are much more interested in the course. We tried to engage Russian students, but to no avail. Our students do not see themselves as entrepreneurs and do not understand why they need it" (U2) or: "We tried to launch it a second time as an open course so that everyone could attend. But we could not make a single team, as we had only four attendees. The course was not launched." (U9)

Students do not see entrepreneurship as a valid career option (U2, U6, U7, U10, U11, U16), therefore statements like the following two have been made: "Almost nobody started their businesses, including those who had big plans and promising results for their project. Students are not sure that entrepreneurship is something one can do" (U11); "We had over 100 [students] over the past two years. The result is always limited to a presentation. Students do not get engaged or believe that it is possible to earn money this way." (U16)

Entrepreneurial culture does not stigmatize failure and it stimulates project development. A lack of such a culture leads to lower commitment and fear of failure (U2, U6, U8, U10, U15). Hence, some respondents mentioned fear of failure or stigma as psychological obstacles on behalf of the students, such as: "They complete the assignment, but they treat it as a study project. I tried to learn what they want. It turned out they are afraid, even those who understand success is possible. They have a familiar place with minimal secure income and they are afraid to lose it and get nothing in return" (U2); "In general, students were not prepared for when their idea went wrong. Some of them accepted it and continued working but others stopped and gave up. I had to ask some students to do their homework for the course" (U15). On a related note, students tend to focus on minor goals and maintain a localized mindset: "Most students are focused on winning a grant with their project as opposed to building a global business. So I help them prepare grant applications and pitch presentations" (U12).

\section{The entrepreneurial course requires new skills from both teachers and students}

Tutors who experimented with different formats pointed out that a classical lecturing format does not work for entrepreneurial courses, as a representative of U2 stressed: "If you provide only lectures without projects, the course is not so lively." In one case, when the course was delivered without the practical aspect, students even took it upon their own initiative to provide it themselves: "Some of the students left the course after the first half and organized a hackathon." (U4)

When the tutor utilized the 'learning by doing' approach and the students were developing their startups, they faced another challenge: students from the same programs faced a lack of diverse skills and knowledge (U4, U13, U15, U19, U20). For such a barrier, the following statement is typical: "There are not enough techies to implement the projects. My students can create a business model, a financial model and promote customer development and write a marketing plan, but they do not know how to make a product, how to code, we do not teach them this" (U4). Some lacked the motivation to master an area far from their main specialization: "To achieve real results, to make startups out of projects, we need interaction between faculties. Engineers are not interested in the marketing part of business, and marketers are not interested in production. There must be internal interaction, they must meet and work together. Currently there is no interaction." (U1)

When combining students from different faculties in the same course, it is important for them to learn

${ }^{6}$ In fact, the Federal State Education Standards do include some entrepreneurial competencies: http://fgosvo.ru/fgosvo/151/150/24 . 
how to communicate with each other: "It is hard for them to work together, because some are humanities scholars, some are engineers, and some are IT focused. They understand and develop in different ways." (U16)

Although this was not in the interview guide, quite a number of tutors (U2, U10, U13, U17, U19) noted that entrepreneurial education should be started from secondary school. For instance: "We tried to work with schoolchildren and we would like to get some help in this regard. Otherwise we have to explain the most basic concepts to students and lose time on that." (U2)

Many of the course tutors do not have entrepreneurial experience (17 universities) and they usually compensate for this through the use of guest speakers and mentors from the entrepreneurial community. However, some tried to establish their own startups in order to understand their students better (U8) and others founded their own startups because they were so inspired by what they had taught their students (U13, U14, U21).

With no regard to experience, the size of the university, or the number of students, tutors desire communication with each other (U8, U10, U13, U16, U18) with the most typically representative quote along the lines of the following: "I feel a need to communicate more with other entrepreneurship tutors and to exchange experiences and best practices" (U10).

\section{When the course is finished: Requirements for student startup mentoring and support at the university}

Twelve out of 21 universities reported that student startups are mentored and supported by a special university unit and are introduced to external accelerators and entrepreneurial support funds. In addition, seven respondents (U1, U7, U8, U11, U12, U16, U21) noted that when the entrepreneurial course ends, the vast majority of students quit their startups and confirmed the need for student startup support and the soft handover of startups from the course to a business incubator. "As long as they are organized according to some format (i.e. the course itself) all of them work- but as soon as the course ends, the connecting element dissolves and everyone runs away. As soon as they face problems, people scatter." (U2)

The challenges with the support of students' startups and mentoring fall into one of two categories: lack of demand for support and lack of supply of support. Setting aside the number of prospective startups that appear from the course, even those students who develop their startups do not apply for external funding (U6, U9, U10, U11). Partly, this is because they do not trust that the procedures are fair at state institutions. One of the teachers pointed out: "They do not want to apply; they do not believe that if they fulfill certain requirements, they will get a result. They think that the state machine is corrupt. I did not get such an impression while working with the Bortnik fund. ${ }^{7}$ But it is difficult to fight prejudice." (U6) Several respondents noticed that students do not apply to the private funds and companies as they are afraid of responsibility (U6, U10, U9). "There was a project with good market potential - greenhouse management. We brought them to a corporation that was eager to use it. But when they understood that it would be not a test, but a real client and a real product, they got scared and the project fell apart." (U6) "We have a regional venture fund, it started to invest in IT-startups as well. Students do not apply as they are not ready to take on responsibility." (U10)

Some students just do not know about the financing and support opportunities: "There is lack of information on government support. Students do not know what the support options are, what a business incubator does, or how it can be useful for them." (U11)

As far as the support provided is concerned, there are various levels of representation. In some instances, there is no support or mentoring available after the course: "We finish the course with the startup pitch but we do not have a tradition of mentoring or supporting startups further. We have a goal to inspire them to continue by themselves. We do not track them and never planned or discussed doing that." (U15)

In some cases, the incubator formally exists, but it does not work in practice (U3, U12, U16). Such a situation was mentioned by respondents: "We have a business incubator, but nothing substantial happens there. There are two projects in the business incubator in total, they are more or less alive" (U3); "We had a startup support center, but it did not work. But it will soon restart." (U16)

A shortage of available experts and staff members is a frequent reason for why startup support at the university is considered insufficient (U9, U13, U14). Even those who have special startup support units note: "We have a one-person commercialization center that helps companies which receive grants to start production" (U5); "We have not yet a sufficient expert/mentor base and only one person at the university who is fully engaged in startup support." (U9)

In a number of cases there is no formal institution for students' startup support and the mentoring is provided by personally motivated individuals, but it ends after they quit their job at the university (U4, U7, U5, U7, U9, U16, U21). So far, "Students create their

Fund for Assistance to Small Innovative Enterprises (FASIE) http://fasie.ru. 
startups during the course and no one mentors them further. We worked with the center of entrepreneurship. But the head of the center quit and there is nothing left there." (U7)

Only a few universities have both online communities for the student-entrepreneurs and co-working spaces for startups (U2, U10, U12, U17, U18, U21), and some lack special spaces for students to work on their projects (U1, U5, U11, U15).

"We have an university incubator, but it does not have an office space where the students can work: the incubator is just a team of people who organize additional educational events and programs." (U5)

Some university representatives mention that their universities do not work with the startup community: "We do not as yet communicate with the startup community." (U14) Some representatives mention that this work is non-systematic or even chaotic (U1, U4, U8, U9, U11, U12, U13, U14, U15, U16), and even those who report regular communication with startups and bring them to students' classes believe that this work is still insufficient (U5, U6, U10, U17), for instance: "We have one representative of Opora Rossii ${ }^{8}$, but he is a lone individual and there is no community." (U16)

Some hold accountable the lack of suitable entrepreneurs (U13, U16): "They are self-made and famous, but there is only few of them in the region." (U13)

Others claim a shortage of financing. As respondents mentioned: "We are limited in our budget. We do not have resources for events" (U7); "the number of members of our entrepreneurial club varies from year to year - from 50 to 200 . Once the club membership reached 500 members, when we had financing. That was five to seven years ago. We were financed through the Federal Law-219 program and we advertised the club and paid performance fees to speakers. This lasted for three years and then stopped. Now we work without external financing. That is why number of members dropped." (U17)

There were also statements showing that students are not active: "Successful entrepreneurs from our city were ready to invest in a good business idea. We announced the startup ideas competition but failed the students are apathetic." (U6)

Some blame the lack of coordination at the university level (U5, U11), for instance: "The issue is not to unite everyone, but to synchronize event schedules so as not to carry out similar events on the same day" (U5), or at the level of regional authorities and stakeholders: "There is no single space for the region. All separate departments have their own programs; there is no single strategy. As a result, we lack synergy and the overall effect is rather small. The administration of our region, the local union of young entrepreneurs, the business incubator, Opora Rossii, the chamber of commerce, and the university- everything is fragmented, everyone is interested in startup development, everyone is doing something, but separately." (U11)

Respondents also complain that lacking mutual consent among the startup ecosystem's stakeholders provokes "grant eaters" (U5, U9, U16). As one of the informants mentioned: "We do not have a value chain - we compete for the same startups, and as a result many activities convert startups into grant eaters. They get a grant, fill out the paperwork, spend the money and instead of working with clients and developing their startup to the next stage, they prepare it for the next competition." (U5)

\section{University ecosystem monitoring}

Only five universities out of 21 reported that they monitor the number of students in entrepreneurial courses, monitor the course feedback, and track the startups after the course ends (U2, U4, U6, U10, U14). Some of them are quite skeptical about the idea of monitoring: "Every university has its KPIs and we have a lot of paperwork to show the formal progress on those KPIs. Top management is happy adhering to their KPIs and we are trying to build a system that will persevere." (U2)

Others believe that the monitoring is unnecessary (U7, U8, U15, U16) or prefer to rely on their assumptions that if they do not see a problem, then it does not exist. For instance: "We do not monitor student entrepreneurs or students' startups. They remain at the ideation level." (U9)

Some universities do not monitor due to a lack of time or knowledge of how to properly implement it and would like some assistance with this: "If you will provide us with a questionnaire for monitoring, we will distribute it and collect the data." (U16)

Our respondents report a broad spectrum of problems indicating that course implementation is catalyzing change, but it is not sufficient to overcome existing issues. This illustrates problems at the university and calls for the consideration of a systematic ecosystem appraisal. The ecosystem framework can be used to diagnose the reasons for student startup failure and highlight areas should be addressed.

\section{Conclusion}

This paper explores how Russian universities implement entrepreneurial courses as accelerating elements for a prospective university entrepreneurial ecosystem.

\footnotetext{
${ }^{8}$ Russian Small and Mediums Sized Entrepreneurs' Association.
} 
First, we identified two approaches to UEE development through case analysis. The systematic approach provides more balanced and holistic ecosystem development through stakeholder coordination and interaction. This approach enabled course promotion (from a single program elective to a compulsory module in several programs), relevant infrastructure development (university business incubator and external partnerships), broad engagement and promotion activities (from schools to university students), and events and support activity coordination among ecosystem stakeholders (case A). The situational approach is focused on solving immediate issues of particular stakeholders including student project development (case $\mathrm{D}$ ) or loading the accelerator pipeline (case C).

Second, it was discovered that the lack of relevant academic background or entrepreneurial experience for the professors, or a variety of course formats did not impede UEE development. High motivation and networking capabilities were invaluable, but a lack of expertise was easily compensated for through ecosystem resources. The key role of a professor through the entrepreneurial course implementation and UEE development was identified as advocating and promoting entrepreneurship to different audiences and developing and enabling connections with the ecosystem actors.

Third, the catalyst function of entrepreneurial courses in student startup development can be dramatically decreased in the absence of other ecosystem elements, such as the university's institutional environment, student engagement and entrepreneurship mainstreaming, the presence of an entrepreneurial course, teachers' training and skill development for the entrepreneurship class, the availability of student startup mentoring and support, startup community engagement, and the systematized presence of university ecosystem monitoring. The highest number of problems were found in the following UEE elements: students' engagement and entrepreneurship mainstreaming and student startup mentoring. Intensive stakeholder interaction stimulates viable student startups, although it is inhibited by the fragmentation of the startup community, adverse institutional environment, and specific regional factors. Moreover, institutions like accelerators and incubators were successful in course implementation and the initiation of UEE development.

Finally, we identified the role of entrepreneurial education in UEE development. A project-focused entrepreneurial class was seen to provide participants with relevant experiences and skills, while also developing an entrepreneurial mindset. Aside from students, other entrepreneurial actors like serial entrepreneurs and business angels are attracted to such courses for mentoring and startup traction activities. Thus, it leads to the establishment of greenfield incubators and accelerators or the establishment of networking relationships with existing institutions. These connections can be established inside a university or with available external institutions.

\section{References}

Alaref J., Brodmann S., Premand P. (2019) The Medium-Term Impact of Entrepreneurship Education on Labor Market Outcomes: Experimental Evidence from University Graduates in Tunisia, Washington, D.C.: The World Bank.

Audretsch D.B., Thurik A.R. (2001) What's new about the new economy? Sources of growth in the managed and entrepreneurial economies. Industrial and Corporate Change, vol. 10, no 1, pp. 267-315.

Autio E., Keeley R.H., Klofsten M., Ulfstedt T. (1997) Entrepreneurial Intent among Students: Testing an Intent Model in Asia, Scandinavia and USA. Frontiers of Entrepreneurship Research. Proceedings of the 17th annual Entrepreneurship Research Conference (ed. P.D. Reynolds), Wellesley, MA: Babson College, pp. 133-147.

Chepurenko A. (2017) How and Why Entrepreneurship Should Be Taught to Students: Polemical Notes. Educational Studies Moscow, no 3, pp. 250-276.

European Commission (2013) Entrepreneurship 2020 Action Plan, Brussels: European Commission.

Fayolle A., Gailly B. (2015) The impact of entrepreneurship education on entrepreneurial attitudes and intention: Hysteresis and persistence. Journal of Small Business Management, vol. 53, no 1, pp. 75-93.

Feld B. (2012) Startup communities: Building an entrepreneurial ecosystem in your city, Hoboken, NJ: Wiley.

Gorman G., Hanlon D., King W. (1997) Some research perspectives on entrepreneurship education, enterprise education and education for small business management: A ten-year literature review. International Small Business Journal, vol. 15, no 3, pp. 56-77.

Greene P., Rice M., Fetters M. (2010) University-based entrepreneurship ecosystems: Framing the discussion. The development of university-based entrepreneurship ecosystems: Global practices (eds. M. Fetters, P. Greene, M. Rice), Cheltenham: Edward Elgar Publishing.

Heron J., Reason P. (2006) The practice of co-operative inquiry: Research 'with' rather than 'on' people. Handbook of Action Research, vol. 2, Thousand Oaks, CA: Sage, pp. 144-154.

Isenberg D. (2011) The entrepreneurship ecosystem strategy as a new paradigm for economic policy: Principles for cultivating entrepreneurship, Dublin: Institute of International and European Affairs. 
Isenberg D. (2014) What an entrepreneurship ecosystem actually is. Harvard Business Review, no 5, pp. 1-7.

Johannisson B. (1991) University Training for Entrepreneurship: A Swedish Approach // Entrepreneurship and Regional Development, vol. 3, no 1, pp. 67-82.

Katz J. (2003) The chronology and intellectual trajectory of American entrepreneurship education 1876-1999. Journal of Business Venturing, vol. 18, no 2, pp. 283-300.

Korotkov A., Zobnina M. (2019) Standarty predprinimatel'skoi ekosistemy universiteta: Rekomendatsii po razvitiyu predprinimatel'skoi ekosistemy [University entrepreneurial ecosystem standards: recommendations for the development of the entrepreneurial ecosystem], Moscow: HSE (in Russian).

Luthje C., Kranke N. (2003) The Making of an Entrepreneur: Testing a Model of Entrepreneurial Intent among Engineering Students at MIT. R\&D Management, vol. 33, no 2, pp. 135-147.

Mason C., Brown R. (2014) Entrepreneurial ecosystems and growth oriented entrepreneurship, Paris: OECD.

Pittaway L., Cope J. (2007) Entrepreneurship education: A systematic review of the evidence. International Small Business Journal, vol. 25, no 5, pp. 479-510.

RVC (2016) National report on innovations in Russia, 2016, Moscow: RVC, Open Government, RF Ministry of Economic Development. Режим доступа: https://www.rvc.ru/upload/iblock/6c5/20161025_2200_Forum_OI_eng.pdf, дата обращения 10.07.2019.

RVC (2017) Impact assessment of university-linked business incubators and accelerators, Moscow: RVC, UBI Global, HSE. Режим доступа: https://www.rvc.ru/upload/iblock/c78/UBI_Global-Russia-Impact_Assessment_University-Linked_ Business_Incubators_Accelerators_EN.pdf, дата обращения 10.07.2019.

Valerio A., Parton B., Robb A. (2014) Entrepreneurship education and training programs around the world: Dimensions for success, Washington, D.C.: The World Bank.

van de Ven A. (1993) The development of an infrastructure for entrepreneurship. Journal of Business Venturing, vol. 8, pp. 211-230.

WEF (2009) Global Education Initiative. Educating the Next Wave of Entrepreneurs, Geneva: World Economic Forum. 